University of Nebraska - Lincoln

DigitalCommons@University of Nebraska - Lincoln

October 2005

\title{
The Finding of Echinostoma (Trematoda: Digenea) and Hookworm Eggs in Coprolites Collected From a Brazilian Mummified Body Dated 600-1,200 Years Before Present
}

\author{
L. Sianto \\ Escola Nacional de Saude Publica-Fundacao Oswaldo Cruz, Rio de Janeiro, Brazil, \\ adauto@ensp.fiocruz.br \\ Karl J. Reinhard \\ University of Nebraska at Lincoln, kreinhard1@mac.com \\ M. Chame \\ Escola Nacional de Saude Publica-Fundacao Oswaldo Cruz, Rio de Janeiro, Brazil \\ S. Chaves \\ Escola Nacional de Saude Publica-Fundacao Oswaldo Cruz, Rio de Janeiro, Brazil \\ S. Mendonça \\ Escola Nacional de Saude Publica-Fundacao Oswaldo Cruz, Rio de Janeiro, Brazil \\ See next page for additional authors \\ Follow this and additional works at: https://digitalcommons.unl.edu/natrespapers \\ Part of the Natural Resources and Conservation Commons
}

Sianto, L.; Reinhard, Karl J.; Chame, M.; Chaves, S.; Mendonça, S.; Gonçalves, M. L. C.; Fernandes, A.;

Ferreira, L. F.; and Araújo, A., "The Finding of Echinostoma (Trematoda: Digenea) and Hookworm Eggs in Coprolites Collected From a Brazilian Mummified Body Dated 600-1,200 Years Before Present" (2005).

Papers in Natural Resources. 92.

https://digitalcommons.unl.edu/natrespapers/92

This Article is brought to you for free and open access by the Natural Resources, School of at DigitalCommons@University of Nebraska - Lincoln. It has been accepted for inclusion in Papers in Natural Resources by an authorized administrator of DigitalCommons@University of Nebraska - Lincoln. 


\section{Authors}

L. Sianto, Karl J. Reinhard, M. Chame, S. Chaves, S. Mendonça, M. L. C. Gonçalves, A. Fernandes, L. F. Ferreira, and A. Araújo 


\section{The Finding of Echinostoma (Trematoda: Digenea) and Hookworm Eggs in Coprolites Collected From a Brazilian Mummified Body Dated 600-1,200 Years Before Present}

L. Sianto, K. J. Reinhard ${ }^{\star}$, M. Chame, S. Chaves, S. Mendonça, M. L. C. Gonçalves, A. Fernandes, L. F. Ferreira, and A. Araújo, Escola Nacional de Saude Publica-Fundacao Oswaldo Cruz, Rio de Janeiro, Brazil; *School of Natural Resources Sciences, University of NebraskaLincoln, Lincoln, Nebraska 68588-0340. e-mail: adauto@ensp.fiocruz.br

ABSTRACT: The identification of parasites from ancient cultures expands our list of parasites infective to extant humans. A partially mummified human body from the archeological site of Lapa do Boquete, Minas Gerais State, Brazil, was recently discovered. It was interred between 600 and 1,200 yr ago. Dietary analysis showed that the mummified body was from a society that had a mixed subsistence of agriculture and gathering of wild foods. Coprolites from the body contained numerous helminth eggs. The eggs were identified as those of Echinostoma sp. and hookworm. Hookworm infection in pre-Columbian populations is already established, but this is the first evidence of Echinostoma sp. eggs found in human coprolites. The diagnosis of a true infection, as opposed to false parasitism, is discussed. The possibility of Echinostoma ilocanum infection is discussed, as this is a common species found in humans in the Asiatic region, which could have been introduced in South America in the pre-Columbian period. Alternative possibilities are also considered, including indigenous Brazilian Echinostoma species.
One of the most significant contributions of archeology to parasitology is the documentation of parasite species infective to ancient humans that are not known from the present clinical literature. In some cases, false parasitism is implicated, such as the find of Cryptocotyle lingua eggs in an Alaskan Yupik mummy (Zimmerman, 1998). False parasitism occurs when parasite eggs are passed in the feces of a subject who is not infected with the parasite. In other cases, real infection is implicated, such as the discovery of acanthocephalan eggs in archeological sites of the Great Basin of North America (Fry, 1970). Diagnosing infection from the archeological record is only possible when the physical remains analyzed are of human origin and when the dietary practices of the human population are known (Reinhard et al., 1987; Reinhard, 1988). If these 2 criteria are met, then the possibility of confusing false parasitism with true infection can be reduced.

Archeologists recently excavated the cave, Lapa do Boquete. This site is situated in the Peruaçu River Valley of northern Minas Gerais State, Brazil. The region is characterized by cerrado vegetation com- 


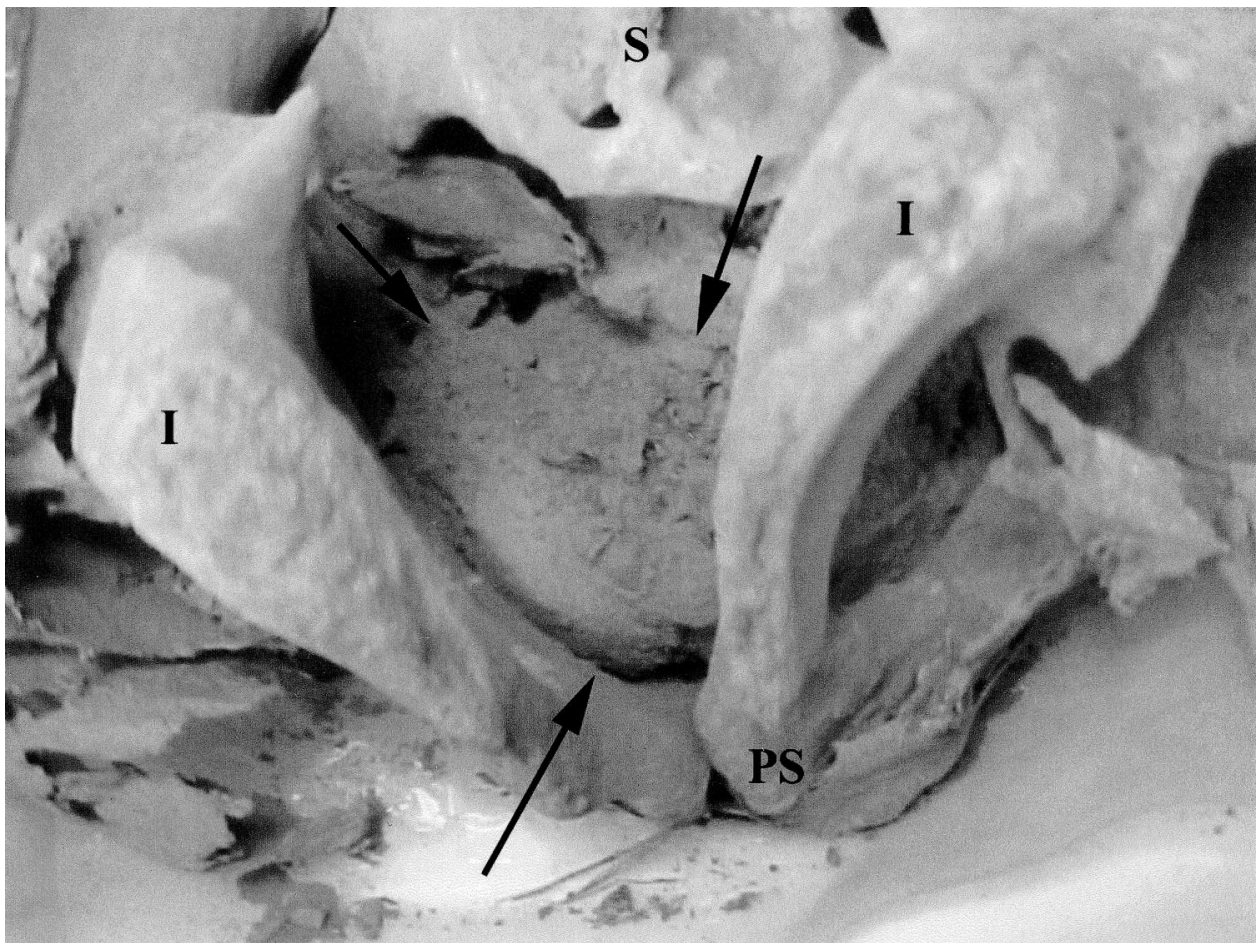

FigURE 1. View of the mummy's pelvic girdle as it was unboxed in the laboratory. $\mathrm{I}=$ ischium, $\mathrm{S}=$ sacrum, $\mathrm{PS}=$ pubic symphysis. Arrows point to a large coprolite that has come to rest on the anterior bones of the pelvic girdle.

posed of stunted, twisted trees. There are also gallery forests along the rivers. Lapa do Boquete is located in the environmentally protected area of Cavernas do Peruaçu (Peruaçu Caves), covering 1,440 $\mathrm{km}^{2}$ (IBAMA, 2003). The site is a multiple-use rock shelter occupied by an extinct society that practiced a mixed subsistence of agriculture, gathering of wild plants, and hunting. The occupation dates between 600 and 1,200 yr ago. Currently, archeologists are refining the date for the burials. The site was used partly as a food-storage area. Burials were also deposited in the site, sometimes in abandoned food-storage pits. The burials were flexed in fetal position (Prous and Schlobach, 1997). One of the burials was partially mummified. Coprolites (desiccated feces) were recovered from the inside of the pelvic girdle and submitted for dietary and parasitological analysis (Fig. 1).

This analysis followed the coprolite paleonutrition methods and goals as summarized by Reinhard and Bryant (1992). The coprolites were rehydrated in $0.5 \%$ aqueous trisodium phosphate for $72 \mathrm{hr}$. The residues were then passed through a mesh screen, which separates macroscopic from microscopic remains. Microscopic remains, smaller than $300 \mu \mathrm{m}$, were emptied into a beaker. These remains were concentrated by centrifugation and analyzed for starch granules, pollen grains, phytoliths, plant fibers, fungal spores, and other dietary and environmental microfossils. The macrofossils, larger that $300 \mu \mathrm{m}$, were trapped on top of the screen, dried, and identified. Macrofossils included seeds, fruit, other plant tissue, bones, mollusk shells, exoskeleton, hair, and other items.

Two methods of parasitological analysis were used. In the first, the samples were rehydrated in $0.5 \%$ trisodium phosphate aqueous solution for $72 \mathrm{hr}$ (Callen and Cameron, 1960). After rehydration, the samples were crushed in a mortar, screened through double gauze, and allowed to sediment in conical glass jars (Lutz, 1919). The sediment was microscopically examined $(\times 40$ and $\times 100)$. Parasite eggs were measured and digitally photographed.

To quantify the numbers of eggs per gram, a second method (Warnock and Reinhard, 1992) was used; this procedure adapted palynological quantification methods to parasitology. A Lycopodium sp. spore tablet, containing $12,542 \pm 400$ spores was dissolved with $0.5 \mathrm{~g}$ of coprolite in rehydration solution. Lycopodium sp. is a high-latitude organism, not endemic to Minas Gerais State. The rehydrated coprolite was disaggregated with a magnetic stirrer until the microfossils, macrofossils, and added spores were thoroughly mixed. The disaggregated coprolite solution was then poured through a triple gauze mesh into a beaker. The residue on top of the mesh was rinsed with a jet of distilled water until all liberated microfossils had passed through the mesh and into the beaker. The microfossils in the beaker were concentrated by centrifugation. Microscope slides $(\mathrm{n}=30)$ were examined and all parasite eggs and Lycopodium sp. spores were counted. The number of parasite eggs per gram of coprolite was then calculated using the pollen concentration formula of Maher (1981); i.e., parasite eggs/g dry sediment $=([$ eggs counted/Lycopodium counted $] \times 12,542) /$ sediment weight.

The dietary remains were diverse. Manioc (Manihot spp.) fibers and starch granules were observed. Domesticated beans (Phaseolus spp.) were present. Dense, porous, fruit epidermis, probably of the Myrtaceae, was identified. Fish bone, charcoal fragments, fungal spores, and nonspecific starch grains were also observed.

Parasite eggs were identified by morphometry and morphology. We found 5 hookworm eggs, 57-65 $\mu \mathrm{m}$ long and 35-40 $\mu \mathrm{m}$ wide. Hookworm eggs may correspond to Necator americanus or Ancylostoma duodenale, but eggs of the 2 species are undistinguishable by morphological parameters and have nearly the same size. The finding of hookworm eggs adds new data to the knowledge of pre-Columbian distribution of this infection and to the debate of its introduction in the American continent (Araújo et al., 1988; Ferreira and Araújo, 1996; Fuller, 1997; Reinhard et al., 2001).

Unembryonated, operculated, light amber, thin-shelled eggs were identified as those of Echinostoma sp. (Fig. 2). Typical of Echinostoma species, the eggs have a slight shell thickening opposite the operculum. Thirty-six eggs were measured; their lengths ranged from 90 to 108 and the width from $55-73 \mu \mathrm{m}$ (mean size: $100 \times 65 \mu \mathrm{m}$, SD: 4.57). Only the measurements of nondeformed eggs with opercula were considered for diagnosis. There were 8,300 Echinostoma eggs per gram of coprolite.

The diagnosis of Echinostoma sp. was achieved after consulting available morphology and measurement data of trematode and cestode eggs. Echinostomatidae species parasitize all vertebrate classes and have numerous mollusk species as intermediate hosts, as well as tadpoles, planarians, and fishes (Roberts and Janovy, 2000). Egg measurements among Echinostoma species range within 62-128 $\mu \mathrm{m}$ (length) and 38$86 \mu \mathrm{m}$ (width) and correspond to the measurements of the eggs found. 


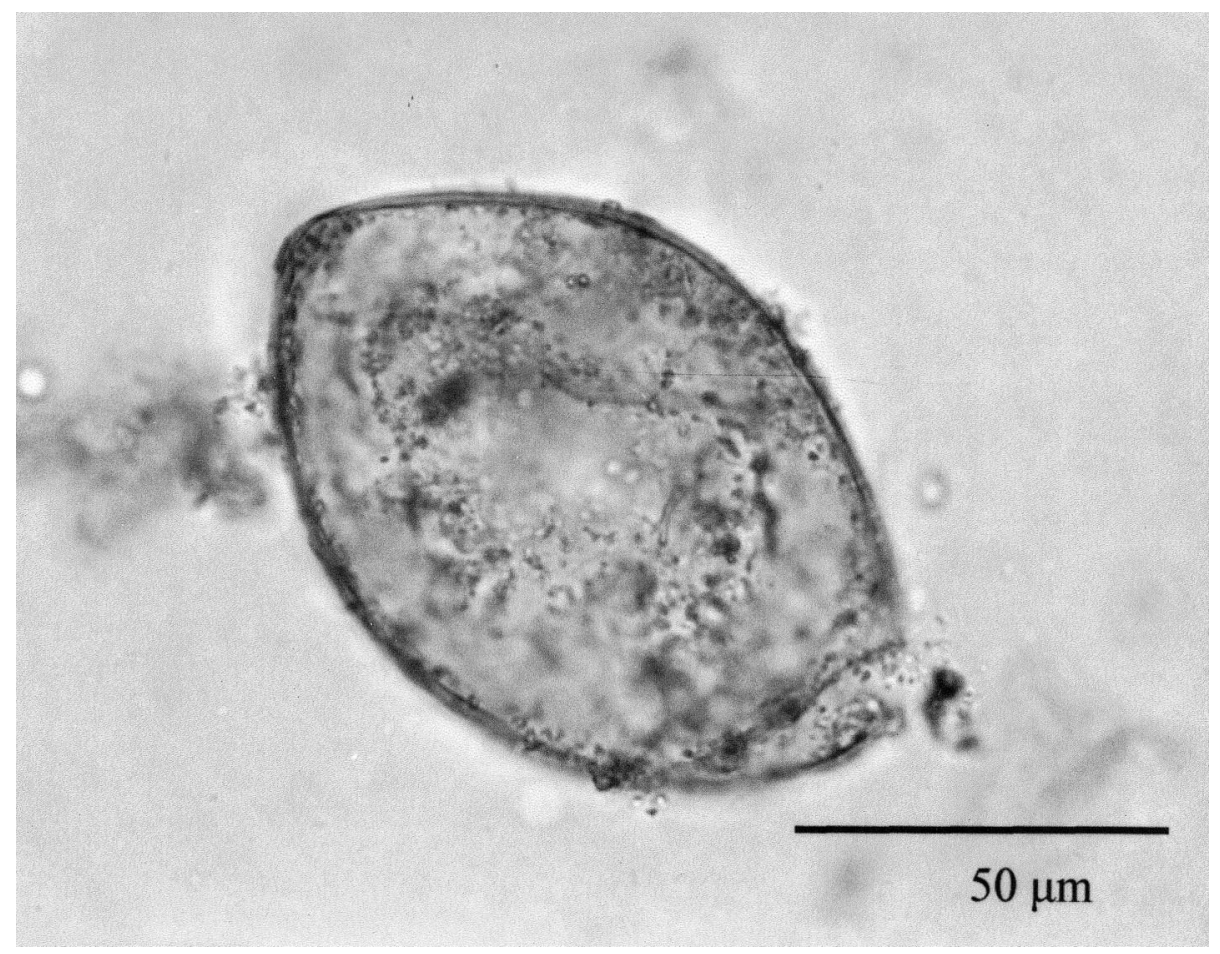

FIGURE 2. Echinostoma sp. egg from the coprolite.

Echinostomatidae, Fasciolidae (Trematoda), Dyphillobothrium spp. (Cestoda), and Paragonimus spp. (Trematoda) eggs have similar morphological characteristics and may be misdiagnosed if morphological details and size are not considered. Careful analysis eliminated misdiagnosis with these taxa. The eggs found in the coprolites did not show the characteristic operculum shield of Paragonimus species. Fasciola hepatica (Fasciolidae) eggs are morphologically identical to the ones in the coprolites analyzed but differ in size (length of $130 \mu \mathrm{m}$ ). Diphyllobothrium sp. eggs have been found in South American human coprolites and identified as Diphyllobothrium pacificum (Patrucco et al., 1983; Ferreira et al., 1984). Diphyllobothrium latum eggs have been found in European organic remains (Bouchet et al., 2003). Reinhard and Urban (2003) discovered that D. pacificum eggs from mummy coprolites are smaller than eggs in coprolites from latrines. They stated that this is probably due to the decomposition of adult worms that liberated immature eggs in the corpse intestinal tract. However, both $D$. pacificum as $D$. latum egg sizes are smaller than the eggs found in this study.

Echinostomiasis is an infectious disease known in some Asian countries; it may cause anemia, diarrhea, eosinophilia, and abdominal pain (Graczyk and Fried, 1998). Humans are infected by ingesting raw or undercooked mollusk, fishes, or frog meat containing the larvae (Roberts and Janovy, 2000). The species most commonly found in the Philippines and Indonesia infecting humans is Echinostoma ilocanum. Infections in communities often follow a familial trend due to shared food preferences, food habits, and preparation methods. The eggs of this species have the same size $(83-116 \mu \mathrm{m} \times 58-69 \mu \mathrm{m})$ and are morphologically identical to the eggs found in the mummy coprolite (Cheng, 1973)

There are 25 known Echinostoma species in Brazilian vertebrate hosts (Travassos et al., 1969; Maldonado et al., 2001). A record of human infection in Brazil caused by Echinostoma echinatum was made by Fried and Graczyk (2000), but it was considered as an isolated case, probably acquired outside the continent.

Recently, a new species was recorded in Brazil, i.e., Echinostoma luisreyi (Maldonado et al., 2003); its egg measurements range within 89-113 $\mu \mathrm{m}$ (length) and 65-82 $\mu \mathrm{m}$ (width), sharing similar measurements to those eggs found in the coprolites. The parasite was found in a mollusk, Physa marmorata. Other known American Echinostoma species have egg measurements outside the range of the eggs found in the mummy. The possibility of the parasite involved being Echinostoma ilocanum is remote, and a more likely explanation points to E. luisreyi infection. Considering egg size and morphology, this is probably the first human occurrence of E. luisreyi. However, we must reserve judgment until a statistical analysis of eggs from all Brazilian echinostomid species is completed.

It is important to consider the possibility that the eggs found in this mummy were the result of false infection. False infections have been recorded from the archeological record from Utah to Alaska (Reinhard, 1990) and resulted when prehistoric humans ate entire, small animals, including the viscera. Usually, small animals, such as rodents and mouth-sized fish, were eaten whole (Reinhard, 1992). Reinhard and Bryant (1992) note that hair, animal bone, and certain fungal species were ingested when entire animals were eaten. Reinhard (1990) asserted that determination of actual infection must be based on a knowledge of prehistoric dietary practices and a measurement of the number of eggs per gram. If bone, hair, or dietary residues of a nonhuman host animal are found in a human coprolite with eggs of a parasite infective to the animal, then false parasitism is implicated. The definitive host of $E$. luisreyi is not known. Hamsters have been infected experimentally (Maldonado et al., 2003), suggesting that the natural host is a small mammal. There is no evidence that a small mammal was part of the mummified individual's last meals. Reinhard (1990) also argues that large numbers of eggs more likely result from true infection, while small numbers or isolated eggs more likely result from false infection. Analysis of the passage of pollen through modern human intestinal tracts (reviewed by Sobolik, 1988) provides insight into the pattern of passage of other microfossils, including parasite eggs. When large amounts of pollen are consumed at a single meal, there is a peak of pollen excretion 2-3 days later. After this peak, pollen-grain concentration depletes such that trace amounts are passed for up to 20 days after ingestion. This is analogous to the consumption of parasite eggs with animal prey. The parasite eggs would be passed fairly rapidly and only trace amounts of eggs would be found just a few days after the prey item was consumed. Therefore, unless the coprolite under study was formed in the few days after consuming an infected prey item, the probability of encountering large numbers of eggs is low. In this case, the numbers of eggs, 8,300 per gram, is high and is consistent with a true infection. Therefore, the absence of prey items in the coprolite, combined with high eggs per gram counts, also suggests a true infection.

It is interesting to hypothesize that the human infection was intro- 
duced in the New World in pre-Columbian times and disappeared without having been noticed until the finding in a mummified body. This is not surprising, as it has happened with other infectious diseases. Dracunculus medinensis, for example, was recorded in Brazilian colonial times among African slaves and actually established a natural focus in the northeast region. However, it disappeared for unknown reasons, and no more cases were recorded (Faust, 1949; Kiple, 1993).

The finding of Echinostoma sp. in a pre-Columbian inhabitant of Brazil shows that this infection existed among prehistoric groups in the region due to food habits that included intermediate host consumption (Morán, 1990; Melatti, 1993; Vieira, 2003). This is the first recovery of Echinostoma spp. from a coprolite and also the oldest diagnosed Echinostoma sp. human infection in South America. The finding of Echinostoma sp. eggs in this mummified body indicates that prehistoric groups were infected by a known parasite species, not recorded for the region, or by an unknown species, capable of infecting humans.

We thank Dr. A. Prous from the Federal University of Minas Gerais and Dr. Arnaldo Maldonado from Oswaldo Cruz Institute/FIOCRUZ. This work was supported by CNPq, CAPES, PAPES-FIOCRUZ, Fulbright Comission. We also thank an anonymous Journal of Parasitology reviewer for substantive comments.

\section{LITERATURE CITED}

Araújo, A. J. G., L. F. Ferreira, U. Confalonieri, and M. Chame. 1988. Hookworm and the peopling of America. Cadernos de Saúde Pública 2: 226-233.

Bouchet, F., N. Guidon, K. Dittmar, S. Harter, L. F. Ferreira, S. M. Chaves, K. Reinhard, and A. Araujo. 2003. Parasite remains in archaeological sites. Memórias do Instituto Oswaldo Cruz 98(Suppl. 1): 47-52.

Callen, E. O., and T. W. M. Cameron. 1960. A pre-historic diet revealed in coprolites. New Scientist 7: 35-40.

Cheng, T. C. 1973. General parasitology. Academic Press Inc., New York, New York, 965 p.

FAust, E. C. 1949. Human helminthology, a manual for physicians, sanitarians and medical zoologists. Lea \& Febiger, Philadelphia, Pennsylvania, $744 \mathrm{p}$.

Ferreira, L. F., AND A. J. G. Araujo. 1996. On hookworms and transpacific contact. Parasitology Today 12: 454.

, U. CONFAlONIERI, AND L. NuÑEZ. 1984. The finding of Diphyllobothrium pacificum in human coprolites (4100-1950 BC) from northern Chile. Memórias do Instituto Oswaldo Cruz 79: 175-180.

FrIED, B., AND T. K. GRACZYK. 2000. Echinostomes as experimental models for biological research. Kluwer Academic Publishers, London, U.K., 273 p

FrY, G. F. 1970. Preliminary analysis of Hogup Cave coprolites. In Hogup Cave, Appendix III. The University of Utah Anthropological Papers 93, C. M. Aikens (ed.). University of Utah Press, Salt Lake City, Utah, p. 247-250.

FUlleR, K. 1997. Hookworm: Not a pre-Columbian pathogen. Medical Anthropology 17: 297-308.

GRACZYK, T. K., AND B. FRIED. 1998. Echinostomiasis: A common but forgotten food-borne disease. The American Journal of Tropical Medicine and Hygiene 58: 501-504.

IBAMA. 2003. Área de Proteção Ambiental Cavernas do Peruaçu/MG. Available on-line on 3 October 2003 [http://www.ibama.gov.br].

KIPLE, K. F. 1993. The Cambridge world history of human disease. Cambridge University Press, Cambridge, U.K., 1776 p.

LuTZ, A. 1919. O Schistosomun mansoni e a schistosomatose segundo observações feitas no Brasil. Memórias do Instituto Oswaldo Cruz 19: $121-155$.

MAHER, L. J. 1981. Statistics for microfossil concentration measurements employing samples spiked with marker grains. Review of Paleobotany and Palynology 32: 153-191.

Maldonado, Jr., A., G. O. Vieira, J. S. Garcia, and L. Rey. 2001 Biological aspects of a new isolate of Echinostoma paraensei (Trematoda: Echinostomatidae): Susceptibility of sympatric snails and the natural vertebrate host. Parasitology Research 87: 853-859.

- , AND R. M. LANFREDI. 2003. Echinostoma luisreyi N. sp. (Platyhelminthes: Digenea) by light and scanning electron microscopy. Journal of Parasitology 89: 800-808.

Melatti, J. C. 1993. Índios do Brasil, 7th ed. Edunb-Hucitec, São Paulo e Brasília, Brazil, 220 p.

MorÁn, E. F. 1990. A ecologia humana das populaçöes da Amazônia. Vozes, Petrópolis, Brazil, 367 p.

Patrucco, R., R. Tello, and D. Bonavia. 1983. Parasitological studies of coprolites of pre-Hispanic Peruvian populations. Current Anthropology 24: 393-394.

Prous, A., AND M. C. SchlobaCh. 1997. Sepultamentos pré-históricos do Vale do Peruaçu-MG. Rev. do Museu de Arqueologia e Etnologia, São Paulo 7: 3-21.

REINHARD, K. J. 1988. Cultural ecology of prehistoric parasitism on the Colorado Plateau as evidenced by coprology. American Journal of Physical Anthropology 77: 355-366.

1990. Archaeoparasitology in North America. American Journal of Physical Anthropology 82: 145-162.

. 1992. Patterns of diet, parasitism, and anemia in prehistoric west North America. In Diet, demography, and disease: Changing perspectives on anemia, P. Stuart-Macadam and S. Kent (eds.). Aldine de Gruyter, New York, New York, p. 219-258.

- G. A. Anderson, And R. H. Hevly. 1987 Helminth remains from prehistoric coprolites on the Colorado Plateau. Journal of Parasitology 73: 630-639.

- A. Araujo, L. F. Ferreira, and C. E. Coimbra. 2001. American hookworm antiquity. Medical Anthropology 20: 96-101.

, AND V. M. BRYANT JR. 1992. Coprolite analysis: A biological perspective on archaeology. In Advances in Archaeological Method and Theory 4, M. B. Schiffer (ed.). University of Arizona Press, Tucson, Arizona, p. 245-288.

, AND O. URBAN. 2003. Diagnosing ancient diphilobothriasis from Chinchorro mummies. Memórias do Instituto Oswaldo Cruz 98(Suppl. 1): 191-193.

Roberts, L. S., AND J. JANOVY JR. 2000. Foundations of parasitology, 6th ed. McGraw-Hill, Boston, Massachusetts, $670 \mathrm{p}$

SoBILIK, K. D. 1988. The importance of pollen concentration values from coprolites: An analysis of southwest Texas samples. Palynology 12: 201-221.

Travassos, L., J. F. Freitas, And A. Kohn. 1969. Trematódeos do Brasil. Memórias do Instituto Oswaldo Cruz 67.

VIEIRA, G. O. 2003. Enteroparasitoses em populações indígenas no Brasil: um estudo meta-analítico qualitativo de produção científica. M.S. Thesis. Escola Nacional de Saúde Pública, Fundação Oswaldo Cruz, Rio de Janeiro, Brazil, 115 p.

WARNOCK, P., AND K. J. REINHARD. 1992. Methods of extracting pollen and parasite eggs from latrine soils. Journal of Archaeological Science 19: 261-264.

Zimmerman, M. R. 1998. Alaskan and Aleutian mummies. In Mummies, disease and ancient cultures, 2nd ed., A. Cockburn, E. Cockburn, and T. A. Reyman (eds.). Cambridge University, Cambridge, U.K., p. 138-153. 